\title{
Conditional Expression in Corticothalamic Efferents Reveals a Developmental Role for Nicotinic Acetylcholine Receptors in Modulation of Passive Avoidance Behavior
}

\author{
Sarah L. King, ${ }^{1}$ Michael J. Marks, ${ }^{2}$ Sharon R. Grady, ${ }^{2}$ Barbara J. Caldarone, ${ }^{1}$ Andrei O. Koren, ${ }^{3}$ Alexey G. Mukhin, ${ }^{3}$ \\ Allan C. Collins, ${ }^{2}$ and Marina R. Picciotto ${ }^{1}$ \\ ${ }^{1}$ Department of Psychiatry, Yale University School of Medicine, New Haven, Connecticut 06508, ${ }^{2}$ Institute for Behavioral Genetics, University of Colorado, \\ Boulder, Colorado 80309, and ${ }^{3}$ Brain Imaging Center, Intramural Research Program, National Institute on Drug Abuse, Baltimore, Maryland 21224
}

\begin{abstract}
Prenatal nicotine exposure has been linked to attention deficit hyperactivity disorder and cognitive impairment, but the sites of action for these effects of nicotine are still under investigation. High-affinity nicotinic acetylcholine receptors (nAChRs) contain the $\beta 2$ subunit and modulate passive avoidance (PA) learning in mice. Using an inducible, tetracycline-regulated transgenic system, we generated lines of mice with expression of high-affinity nicotinic receptors restored in specific neuronal populations. One line of mice shows functional $\beta 2$ subunit-containing nAChRs localized exclusively in corticothalamic efferents. Functional, presynaptic nAChRs are present in the thalamus of these mice as detected by nicotine-elicited rubidium efflux assays from synaptosomes. Knock-out mice lacking high-affinity nAChRs show elevated baseline PA learning, whereas normal baseline PA behavior is restored in mice with corticothalamic expression of these nAChRs. In contrast, nicotine can enhance PA learning in adult wild-type animals but not in corticothalamic-expressing transgenic mice. When these transgenic mice are treated with doxycycline in adulthood to switch off nAChR expression, baseline PA is maintained even after transgene expression is abolished. These data suggest that high-affinity nAChRs expressed on corticothalamic neurons during development are critical for baseline PA performance and provide a potential neuroanatomical substrate for changes induced by prenatal nicotine exposure leading to long-term behavioral and cognitive deficits.
\end{abstract}

Key words: nicotine; learning; transgenic mice; nicotinic acetylcholine receptors; brain; prenatal

\section{Introduction}

The comorbidity of prenatal nicotine exposure with psychiatric disorders and cognitive impairment suggests that nicotinic acetylcholine receptors ( $\mathrm{nAChRs)} \mathrm{may} \mathrm{play} \mathrm{a} \mathrm{role} \mathrm{in} \mathrm{the} \mathrm{etiology} \mathrm{of}$ these disorders. In utero exposure to nicotine can increase the risk of attention deficit hyperactivity disorder (ADHD), lower IQ, and conduct disorder later in life (Ernst et al., 2001; Wakschlag et al., 2002). Determining the nAChR subtypes and the neuroanatomical loci responsible for these effects is difficult using traditional pharmacological approaches because of the large number of nAChR subtypes, their overlapping pharmacological profiles, and their wide distribution in the brain. The thalamus has been implicated in learning and memory, attention, arousal, and emotionality (Masterman and Cummings, 1997; Kalivas et al., 1999). In addition, the thalamus contains the highest density of highaffinity $\mathrm{nAChRs}$ in the brain (composed predominantly of the $\alpha 4$ and $\beta 2 \mathrm{nAChR}$ subunits) (Zoli et al., 1998), but virtually nothing is known about the function of nAChRs in this region. There are two main neuronal types in thalamus: GABAergic interneurons

Received Dec. 9, 2002; revised Jan. 29, 2003; accepted Feb. 12, 2003.

This work was supported by National Institute on Drug Abuse Grants DA00436, DA14241, DA10455, and DA84733 (M.R.P.) and DA03194 and DA00197 (A.C.C). We thank Dr. Eric Nestler for the generous gift of NSE-tTA mice and valuable input on many aspects of this study. We thank Drs. Ronald Duman and Angus Nairn for reading this manuscript and for helpful conversations about this work. We thank Drs. Max Kelz and Jingshan Chen for providing information and primers for characterizing NSE-tTA transgenic mice.

Correspondence should be addressed to Marina R. Picciotto, Department of Psychiatry, Yale University School of Medicine, 34 Park Street, Third Floor Research, New Haven, CT 06508. E-mail: marina.picciotto@yale.edu. Copyright $\odot 2003$ Society for Neuroscience $\quad$ 2270-6474/03/233837-07\$15.00/0 and glutamatergic thalamocortical relay neurons (Guillery and Sherman, 2002). Glutamatergic sensory projections, glutamatergic projections from layer VI of the cortex, and cholinergic pedunculopontine projections all synapse onto thalamic neurons (Hallanger et al., 1987). Functional nAChRs are present at several levels of this system on both cell bodies and terminals (Léna and Changeux, 1997; Lu et al., 1998; Corrigall et al., 1999). The enrichment of high-affinity nAChRs in this region make it a potential target for developmental changes caused by alterations in nicotinic receptor function.

Passive avoidance (PA) is a fear-associated learning test sensitive to manipulations of the cholinergic system and a model for emotional learning in humans. Cholinergic deafferentation of thalamus in rodents, as in thiamine-deficient rats with reduced choline-acetyl-transferase levels in thalamus (and other brain areas), is correlated with impairments in PA learning (Nakagawasai et al., 2000). Senescence accelerated mice also have lower levels of acetylcholine in thalamus and hypothalamus and show impaired PA performance that is rectified by acute, pretrial administration of nicotine (Meguro et al., 1994). $\beta 2 \mathrm{nAChR}$ subunit knock-out ( $\beta 2 \mathrm{ko}$ ) mice lack all high-affinity binding for nicotine and show abnormally high baseline PA and no improvement in learning as a result of post-training nicotine administration when compared with wild-type siblings (Picciotto et al., 1995). To identify where in the brain nicotinic receptors exert their actions on PA learning, transgenic mice with temporally and spatially restricted expression of high-affinity nAChRs were generated and tested in PA. These mice were used to identify the nAChR subtypes and neu- 
ronal populations that appear critical for the long-term behavioral consequences of genetic or pharmacological manipulations of nicotinic neurotransmission.

\section{Materials and Methods}

Animals. The cDNA encoding the $\beta 2$ subunit was generated by reverse transcription (RT)-PCR from mouse brain mRNA (5', TTT AAG CTTGCG CGG CTT CAG CAC CAC GGA CAG CGC; 3', TTT ACT AGTTCC ACC CAA TAC TAC TGA ACC) and subcloned into pTet-splice (Invitrogen, Gaithersburg, MD). The plasmid was sequenced, and the band containing the Tet- $\beta 2$ construct and SV40 $3^{\prime}$ untranslated region was excised, purified by gel electrophoresis, and microinjected into B6SJL oocytes (Yale University Transgenic Facility). Founder mice carrying the transgene were crossed with Line A NSE-tTA mice on the ICR background (Chen et al., 1998; Kelz et al., 1999) and $\beta 2$ ko mice on the C57BL/6J background (Picciotto et al., 1995). C57BL/6J mice were obtained from The Jackson Laboratory (Bar Harbor, ME). Genotyping was performed by PCR on phenol-extracted tail DNA. Mice were crossed to generate $\beta 2$ ko or $\beta 2$ heterozygote ( $\beta 2$ het) offspring with at least one copy of the Tet- $\beta 2$ and NSE-tTA transgenes. Litters of mice on a mixed genetic background of $\beta 2$ wild-type (wt), $\beta 2$ het, and $\beta 2$ ko genotype with copies of one or both of the transgenes were used for behavioral experiments. $\beta 2$ ko mice with both transgenes ( $\beta 2$ tr) expressed the $\beta 2$ subunit inducibly in different brain regions. $\beta 2 \mathrm{tr}, \beta 2 \mathrm{wt}$, and het mice with or without the transgenes (wild type), and $\beta 2$ ko mice with no transgenes or only a single transgene ( $\beta 2 \mathrm{ko}$ ) were compared. Mice were group housed with a maximum of five per cage in a colony room maintained at $22^{\circ} \mathrm{C}$ on a $12 \mathrm{hr} \mathrm{light/dark} \mathrm{cycle,} \mathrm{with} \mathrm{lights} \mathrm{on} \mathrm{at} \mathrm{7:00} \mathrm{A.M.} \mathrm{Food}$ and water were available ad libitum. All animal procedures were in strict accordance with NIH Care and Use of Laboratory Animals Guidelines and were approved by the Yale Animal Care and Use Committee.

PA learning. Testing was performed in a mouse PA chamber (Ugo Basile, Comerio, Italy). On day 1, the mouse was placed in the light chamber and allowed to move freely between the two compartments for $5 \mathrm{~min}$. On day 2 , the mouse was placed in the light chamber, and latency to enter the dark chamber was measured. After entry into the dark chamber, the door between compartments closed, and a 2 sec electric shock $(0.2 \mathrm{~mA})$ was administered through the grid floor. The animal was removed from the apparatus, given an intraperitoneal injection $(10 \mu \mathrm{l} / \mathrm{gm})$ of $0.9 \%$ saline or $10 \mu \mathrm{g} / \mathrm{kg}$ nicotine bitartrate (concentration calculated as free base), and returned to a holding cage. On day 3 , mice were again placed in the light chamber, and time to enter the dark chamber was recorded. Mice used in the initial passive avoidance experiment were aged from 2 to 9 months. No differences in PA behavior were seen with age. Another cohort of mice (aged 4-12 months at testing) was divided into two groups (balanced by genotype, sex, and age), and half were given doxycycline (dox) in their drinking water $(100 \mu \mathrm{g} / \mathrm{ml})$ for 5 to 7 weeks before PA testing.

Shock reactivity test. Shock reactivity was measured as described previously (Caldarone et al., 2000). Mice were given a series of 1 sec shocks starting at $0.05 \mathrm{~mA}$ and increasing to $1 \mathrm{~mA}$ in increments of $0.05 \mathrm{~mA}$, with a 19 sec intershock interval. Mice were scored by two observers for flinch (any observable reaction to the shock), run, jump, or vocalization reactions. For each animal, the experiment was stopped when the mouse had displayed all four reactions. Mean current thresholds to evoke each response were calculated and averaged between observers.

In situ hybridization and equilibrium binding. Mice were decapitated, and brains were removed, frozen on dry ice, and stored at $-80^{\circ} \mathrm{C}$. Sections $(12 \mu \mathrm{m})$ were cut at the cryostat, thaw mounted onto chrom-alumcoated slides [ $0.5 \%$ chromium (III) phosphate- $0.5 \%$ gelatin] for radioligand binding or charged slides (Fisherbrand Superfrost/Plus; Fisher Scientific, Pittsburgh, PA) for in situ hybridization. Sections were dried at room temperature for $20 \mathrm{~min}$ and stored at $-80^{\circ} \mathrm{C}$. The large intracellular loop of the $\beta 2$ subunit (amino acids $338-456$ ) was subcloned into pBluescript. Antisense and sense cRNA probes were transcribed with T7 or SP6 RNA polymerase in the presence of $\left[{ }^{35} \mathrm{~S}\right] \mathrm{UTP}$ (NEN, Boston, MA) and purified through RNA mini-quick-spin columns (Roche, Indianapolis, IN). Brain sections were postfixed in $4 \%$ paraformaldehyde in $1 \times$
PBS (in mm: $1 \mathrm{KH}_{2} \mathrm{PO}_{4}, 10 \mathrm{Na}_{2} \mathrm{HPO}_{4}, 1.37 \mathrm{NaCl}$, and $2.7 \mathrm{KCl}$, pH 7.4), acetylated for $15 \mathrm{~min}$ in $0.1 \mathrm{M}$ tetraethylammonium and $0.25 \%$ acetic anhydride, and dehydrated through an ethanol series. Slides were hybridized overnight at $60^{\circ} \mathrm{C}\left(10^{6} \mathrm{cpm}\right.$ per slide), washed in $2 \times \operatorname{SSC}(0.3 \mathrm{~m}$ sodium acetate and $0.03 \mathrm{~m}$ sodium citrate), treated with $20 \mu \mathrm{g} / \mathrm{ml}$ RNaseA (Roche), washed in descending concentrations of SSC (to $0.1 \times$ ) at $55^{\circ} \mathrm{C}$, rinsed with water, dried, and exposed to ${ }^{3} \mathrm{H}$-Hyperfilm (Amersham Biosciences, Arlington Heights, IL) for $15 \mathrm{~d}$.

For radioligand binding, sections were thawed at room temperature and incubated with $200 \mathrm{pm}\left[{ }^{125} \mathrm{I}\right] \mathrm{A} 85380$ for $30 \mathrm{~min}$ in $50 \mathrm{~mm}$ Tris-HCl, pH7.4, washed twice in the same buffer, dried, and exposed to ${ }^{3} \mathrm{H}$ Hyperfilm for 2-7 d.

Tissue preparation and rubidium efflux. Mice were killed, and brain regions were dissected on ice. Samples were homogenized in cold isotonic sucrose ( $0.32 \mathrm{~m}$ sucrose with $5 \mathrm{~mm}$ HEPES, pH 7.5) in a tissue grinder with 16 strokes by hand. Homogenates were centrifuged at $12,000 \times g$ for $20 \mathrm{~min}$, and pellets were resuspended in different buffers depending on the following assay. Rubidium efflux experiments were performed as described previously (Marks et al., 2002). Briefly, homogenized and centrifuged tissue was resuspended in buffer A (in mM: 140 $\mathrm{NaCl}, 1.5 \mathrm{KCl}, 2 \mathrm{CaCl}_{2}, 1 \mathrm{MgSO}_{4}, 20$ glucose, and 20 HEPES hemisodium, $\mathrm{pH} 7.5)$. Aliquots $(25 \mu \mathrm{l})$ were incubated with $4 \mu \mathrm{Ci}$ of $\left[{ }^{86} \mathrm{Rb}^{+}\right]$ for $30 \mathrm{~min}$ at $22^{\circ} \mathrm{C}$ in a final volume of $35 \mu \mathrm{l}$. Uptake was terminated by filtration of each sample onto a Gelman $\mathrm{A} / \mathrm{E}$ glass fiber filter under gentle vacuum and washing once with $0.5 \mathrm{ml}$ of buffer A. The washed filters were transferred to a polypropylene platform and superfused with buffer B (135 mм NaCl, 5 mм CsCl, $1.5 \mathrm{~mm} \mathrm{KCl,} 1$ mm $\mathrm{MgSO}_{4}, 2 \mathrm{~mm} \mathrm{CaCl}_{2}, 20$ mM glucose, $50 \mathrm{~nm}$ tetrodotoxin, $1 \mu \mathrm{m}$ atropine, $20 \mathrm{~mm}$ HEPES hemisodium, and $0.1 \%$ bovine serum albumin, $\mathrm{pH} 7.5$ ). Buffer was applied at a rate of $2.5 \mathrm{ml} / \mathrm{min}$ and was actively removed with a second peristaltic pump set for a flow rate of $3.2 \mathrm{ml} / \mathrm{min}$. The buffer was pumped through a $200 \mu \mathrm{l}$ Cherenkov cell in $\alpha$-RAM Radioactivity HPLC detector (IN/US Systems, Tampa, FL) to allow continuous monitoring of radioactivity. Samples were stimulated by diverting the application buffer through a $200 \mu \mathrm{l}$ loop containing the test solution (30 $\mu \mathrm{m}$ nicotine). Stimulation time was $5 \mathrm{sec}$. Baseline efflux was calculated using points before and after stimulation. Magnitude of $\left[{ }^{86} \mathrm{Rb}^{+}\right]$efflux was calculated as stimulation above basal and normalized to basal efflux to allow comparison among regions and genotypes.

Epibatidine binding. Epibatidine binding was performed as described previously (Marks et al., 2002). Samples were incubated in a 96-well polystyrene plate for $2 \mathrm{hr}$ at $22^{\circ} \mathrm{C}$. Final incubation was in $30 \mu \mathrm{l}$ of binding buffer. Binding reactions (200 pM $\left[{ }^{125} \mathrm{I}\right]$ epibatidine) were terminated by filtration onto Gelman A/E glass fiber paper that had been treated with $0.5 \%$ polyethylenimine. Samples were washed six times with cold load buffer. Bound ligand was quantified using a Packard Cobra Gamma Counter. Counting efficiency was $85 \%$. Blanks were determined with $100 \mu \mathrm{M}$ nicotine, and all results presented are specific binding.

GABA release. [ ${ }^{3} \mathrm{H}$ ] GABA release from synaptosomes was performed as described previously (Lu et al., 1998). Homogenates from cortex, thalamus, hippocampus, and striatum were centrifuged at $12,000 \times g$ for 20 $\mathrm{min}$. The resulting crude synaptosomal pellet was resuspended in uptake buffer (in mm: $128 \mathrm{NaCl}, 2.4 \mathrm{KCl}, 1.2 \mathrm{KH}_{2} \mathrm{PO}_{4}, 1.2 \mathrm{MgSO}_{4}, 3.2 \mathrm{CaCl}_{2}, 25$ HEPES, and 10 glucose, $\mathrm{pH} 7.5$ ) and incubated with $1 \mathrm{~mm}$ aminooxyacetic acid at $37^{\circ} \mathrm{C}$ for $10 \mathrm{~min}$. $\left[{ }^{3} \mathrm{H}\right] \mathrm{GABA}(0.1 \mu \mathrm{M})$ and unlabeled GABA $(0.25 \mu \mathrm{M})$ were added and incubated $10 \mathrm{~min}$ at $37^{\circ} \mathrm{C}$. Aliquots were collected onto glass fiber filters and washed with $0.5 \mathrm{ml}$ of perfusion buffer (119 mm NaCl, $3.6 \mathrm{~mm} \mathrm{KCl,} 1.2 \mathrm{~mm} \mathrm{MgSO}_{4}, 10 \mathrm{~mm} \mathrm{CsCl,} 3.2 \mathrm{~mm}$ $\mathrm{CaCl}_{2}, 25$ mм HEPES, 10 mm glucose, and 0.1\% BSA, pH 7.5). Perfusion buffer was pumped over synaptosomes at $1.8 \mathrm{ml} / \mathrm{min}$ (RT). Release was stimulated by a $12 \mathrm{sec}$ exposure to $30 \mu \mathrm{M}$ L-nicotine. Data (as counts per minute released per fraction) were corrected for baseline release from fractions collected before and after the agonist stimulation. Data were then normalized to baseline, and fractions in which release exceeded baseline by $10 \%$ or more were summed. Units of release are as fraction of baseline. 


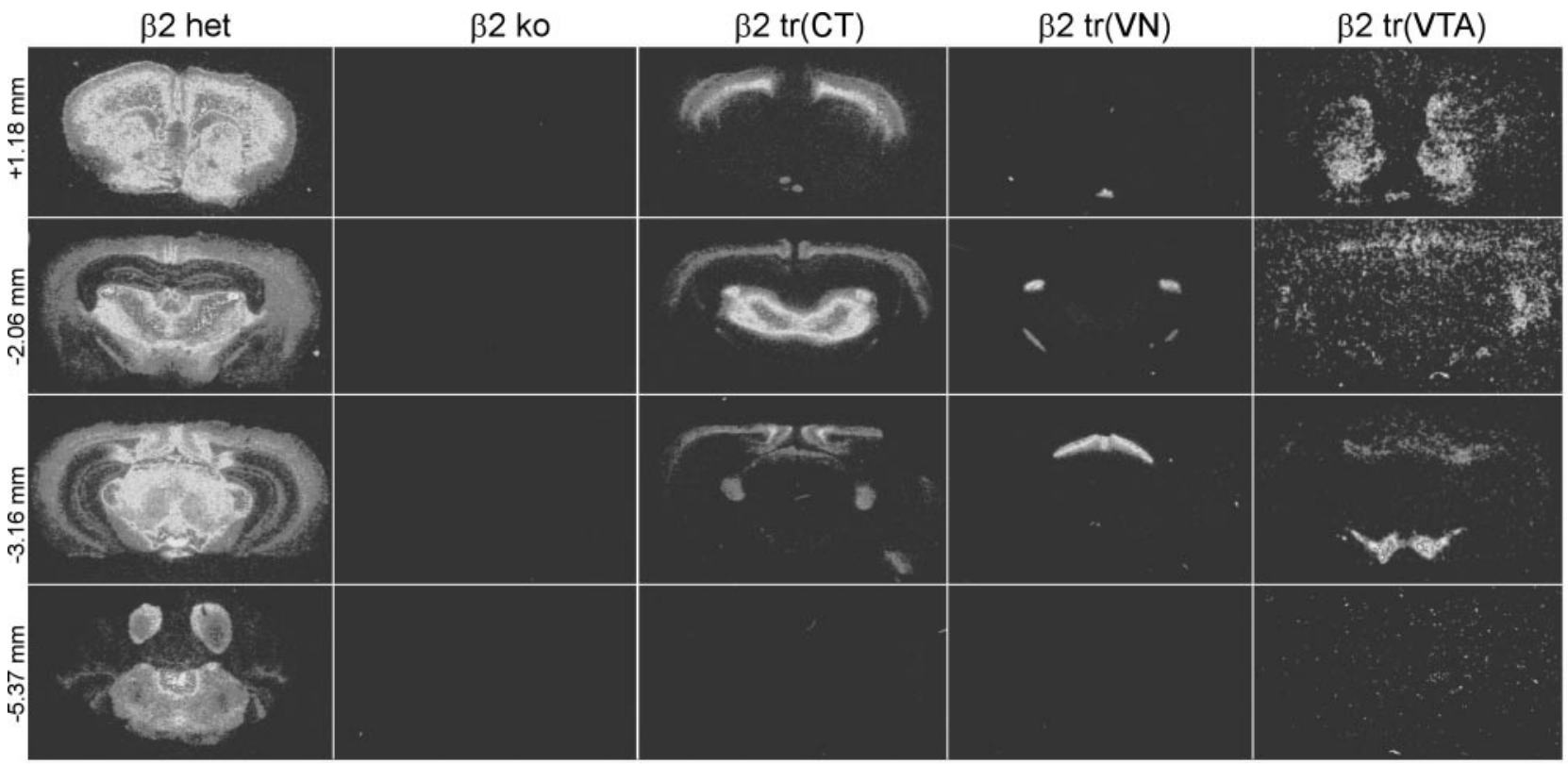

Figure 1. Transgenic mice with region-specific expression of $\beta 2$ subunit-containing nAChRs. Mice from three transgenic lines carrying the NSE promoter driving expression of the tetracycline transactivator (NSE-tTA) (Chen et al., 1998; Kelz et al., 1999) were crossed with mice carrying the TetOp promoter driving the $\beta 2$ subunit (Tet0p- $\beta 2$ ) on a $\beta 2$ ko background. [25 I]A85380 binding is shown in $\beta 2$ het, $\beta 2 \mathrm{ko}$, and three lines of $\beta 2$ tr mice (CT, VN, and VTA). Bregma coordinates are shown for the four levels (Paxinos and Franklin, 1997).

\section{Results}

Inducible, region-specific expression of $\beta 2$ subunit-containing nAChRs

Transgenic mice were generated that express the $\beta 2$ subunit of the nAChR under the control of a tetracycline-regulated promoter (TetOp- $\beta 2$ ). Founder mice were crossed with $\beta 2$ ko mice carrying a transgene encoding the neuron-specific enolase promoter driving expression of the tetracycline transactivator (NSEtTA). In $\beta 2$ tr mice, all $\beta 2$ subunit-containing $\mathrm{nAChRs}$ in the brain were expressed from the tetracyline-regulatable transgene. Equilibrium binding using the nicotinic agonist $\left[{ }^{125} \mathrm{I}\right]$ epibatidine in brain slices identified three TetOp- $\beta 2$ lines of mice with increased densities of high-affinity binding sites (data not shown). Region-specific patterns of binding were similar in all three lines, and one line was picked for further characterization. This line was crossed to three different NSE-tTA founder lines (Chen et al., 1998; Kelz et al., 1999). Equilibrium binding studies using $\left[{ }^{125} \mathrm{I}\right] \mathrm{A} 85380$, a nicotinic ligand specific to $\beta 2$-containing nAChRs (Mukhin et al., 2000), showed distinct patterns of expression in each of the NSE-tTA lines (Fig. 1). High-affinity nicotinic binding in $\beta 2 \operatorname{tr}(\mathrm{CT})$ mice was restricted to cortex and thalamus. $\beta 2 \operatorname{tr}(\mathrm{VN})$ mice expressed high-affinity nAChRs in the optic tract, visual nuclei of the thalamus, and superior colliculus. $\beta 2 \operatorname{tr}(\mathrm{VTA})$ mice showed high-affinity nicotinic binding predominantly in nucleus accumbens, substantia nigra, ventral tegmental area, and striatum. In contrast, $\beta 2$ het siblings of the $\beta 2 \mathrm{tr}$ mice showed A85380 binding throughout the brain, and $\beta 2$ ko mice had no detectable binding. As a result of the enrichment of nicotine binding in thalamus and cortex in the $\beta 2 \operatorname{tr}(\mathrm{CT})$ transgenic mice, this line was selected for further characterization in neurochemical and behavioral paradigms.

\section{Inducible expression in $\beta 2 \operatorname{tr}(\mathrm{CT})$ mice is restricted to corticothalamic projection neurons}

Nicotinic ligand binding was performed on membranes isolated from several brain regions to provide a quantitative measure of high-affinity nAChRs expressed in $\beta 2 \operatorname{tr}(\mathrm{CT})$ mice (Fig. $2 A$ ).
There was a clear effect of $\beta 2$ subunit gene dosage on epibatidine binding in most brain areas across $\beta 2 \mathrm{wt}$, het, and ko mice, as has been reported previously (Marks et al., 1999); however, $\beta 2$ $\operatorname{tr}(\mathrm{CT})$ mice showed significant epibatidine binding in the cortex and thalamus only. In situ hybridization was performed using the intracellular loop region of the $\beta 2$ subunit as a probe in $\beta 2 \operatorname{tr}(\mathrm{CT})$ mice. $\beta 2$ subunit mRNA was detected specifically in layer VI of the cerebral cortex, CA1, and dentate gyrus of the hippocampal formation and throughout the dorsal striatum, but no specific hybridization was seen in the thalamus (Fig. $2 B$ ). This pattern is similar to that seen for other genes of interest driven by the same NSE-tTA line (Chen et al., 1998; Kelz et al., 1999). Ectopic expression of the $\beta 2$ subunit transgene in cells not normally expressing the heteromeric nAChRs does not result in the production of assembled nAChRs or high-affinity nicotinic radioligand binding because the $\beta 2$ subunit can only form a functional channel in the presence of its partner subunits (Luetje and Patrick, 1991). The equilibrium binding data coupled with the in situ hybridization studies suggest that $\beta 2 \operatorname{tr}(\mathrm{CT})$ mice express functional highaffinity nAChRs only in corticothalamic projection neurons.

\section{Functional characterization of $\beta 2 \mathrm{nAChRs}$ in corticothalamic terminals}

To confirm that nicotinic binding in the thalamus represents functional, terminal nAChRs and to identify the neurotransmitter released from these neurons, synaptosomal fractions were collected from several brain areas and were assayed for rubidium $\left[{ }^{86} \mathrm{Rb}\right]$ efflux (Fig. $3 A$ ) and $\left[{ }^{3} \mathrm{H}\right]$ GABA release (Fig. $3 B$ ). The $\left[{ }^{86} \mathrm{Rb}^{+}\right]$efflux assay measures the opening of functional nicotinic receptor channels in synaptosomes in response to nicotine stimulation (Marks et al., 1995). The expected gene dosage response in $\left[{ }^{86} \mathrm{Rb}^{+}\right]$efflux stimulated by nicotine was seen across $\beta 2 \mathrm{wt}$, het, and ko mice (Fig. 3A) (Marks et al., 1999). A significant increase in $\left[{ }^{86} \mathrm{Rb}^{+}\right]$efflux was seen in the thalamus of $\beta 2$ $\operatorname{tr}(\mathrm{CT})$ compared with $\beta 2$ ko mice. Efflux was similar to that seen in $\beta 2$ het mice, suggesting that $\beta 2 \operatorname{tr}(\mathrm{CT})$ mice express physiologically relevant levels of high-affinity nAChR (Fig. 3A). There 

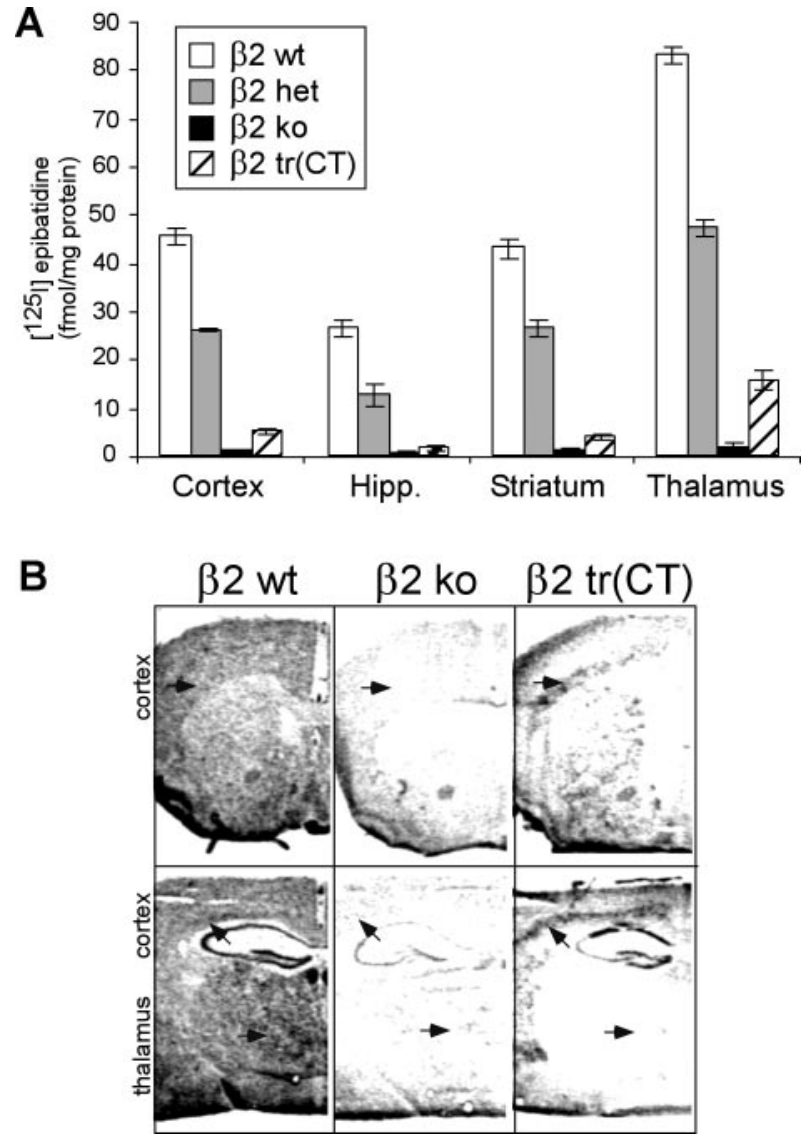

Figure 2. $\quad \beta 2$ subunit-containing $\mathrm{nAChRs}$ are expressed in the cortex and thalamus of $\beta 2$ $\operatorname{tr}(\mathrm{CT})$ mice. $A$, Quantitiative epibatidine binding in microdissected brain regions of $\beta 2 \mathrm{wt}$, het, $\mathrm{k}$, and $\beta 2 \operatorname{tr}(\mathrm{CT})$ transgenic mice ( $n=3$ for each genotype). ANOVA showed a significant effect of genotype on binding $(p<0.0001)$. Post hoc Newman-Keuls tests showed the $\beta 2 \mathrm{wt}$ and $\beta 2$ het mice to be different from each other and all other genotypes for all brain areas $(p<$ 0.05 ). The $\beta 2 \operatorname{tr}(\mathrm{CT})$ mice had greater binding than $\beta 2 \mathrm{ko}$ mice in the cortex and thalamus ( $p<$ 0.05 ). Binding in the hippocampus (Hipp.) and striatum did not differ between $\beta 2 \operatorname{tr}(\mathrm{CT})$ and $\beta 2$ ko mice $(p>0.05)$. $B$, In situ hybridization with an antisense riboprobe against the large intracellular loop region of the $\beta 2$ subunit at the level of the thalamus (bregma $+1.10 \mathrm{~mm}$ ) and prefrontal cortex (bregma $-1.70 \mathrm{~mm}$ ). Arrows point to the thalamus and layer $\mathrm{VI}$ of the cortex.

was no increase in $\left[{ }^{86} \mathrm{Rb}^{+}\right.$] efflux in cortical synaptosomes from $\beta 2 \operatorname{tr}(\mathrm{CT})$ mice above levels seen in $\beta 2$ ko mice, demonstrating that nicotinic binding in this brain region is on cell bodies rather than neuronal terminals. Furthermore, no release was seen in striatum or hippocampus of $\beta 2 \operatorname{tr}(\mathrm{CT})$ mice, as expected from the lack of nicotinic binding in these brain areas.

Both GABAergic and glutamatergic terminals in the thalamus express high-affinity nAChRs in wild-type mice. We therefore measured $\left[{ }^{3} \mathrm{H}\right] \mathrm{GABA}$ release from synaptosomes in response to treatment with $30 \mu \mathrm{M}$ nicotine to identify the neuronal subtypes expressing functional high-affinity $\mathrm{nAChRs}$ in $\beta 2 \operatorname{tr}(\mathrm{CT})$ mice. As expected, $\beta 2 \mathrm{wt}$ and het mice showed increased $\left[{ }^{3} \mathrm{H}\right] \mathrm{GABA}$ release in response to nicotine treatment compared with $\beta 2$ ko mice (Lu et al., 1998). In contrast, $\beta 2 \operatorname{tr}(\mathrm{CT})$ mice show no increased GABA release over the level seen in $\beta 2$ ko mice in any of the brain areas tested (Fig. 3B). This implies that these transgenic mice do not express high-affinity nAChRs in GABAergic neurons. Thus, nicotinic binding, in situ hybridization, and release data together suggest that $\beta 2 \operatorname{tr}(\mathrm{CT})$ mice express high-affinity $\mathrm{nAChRs}$ in glutamatergic, layer VI cortical neurons projecting to
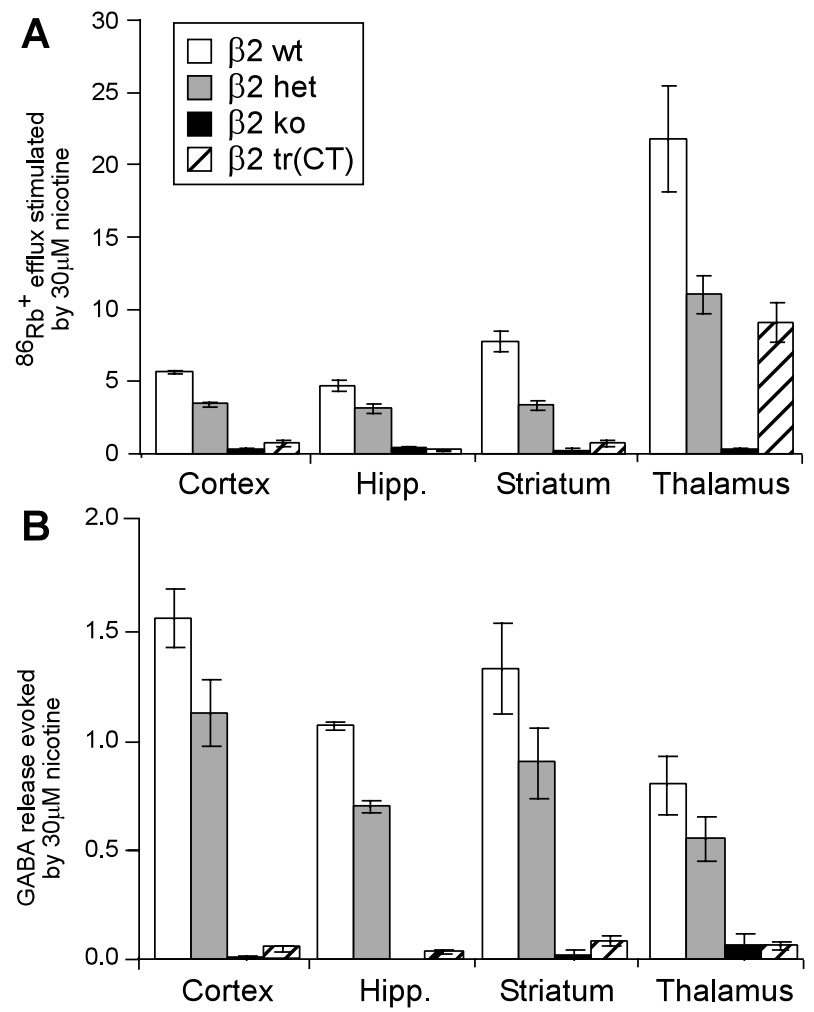

Figure 3. $\quad \beta 2 \operatorname{tr}(C \mathrm{C})$ mice have functional expression of $\beta 2$ subunit-containing $\mathrm{nAChRs}$ on thalamic terminals of cortical projection neurons. $A$, Effect of genotype on nicotine-evoked rubidium efflux (30 $\mu \mathrm{m}$ nicotine) from synaptosomal preparations of microdissected brain regions ( $n=4$ for each genotype). ANOVA showed a significant effect of genotype on [ $\left.{ }^{86} \mathrm{Rb}\right]$ efflux in all brain areas $(p<0.0001)$. Post hoc Newman-Keuls tests showed the $\beta 2$ wt mice to be different from all other genotypes in all brain areas $(p<0.05)$. The $\beta 2 \operatorname{tr}(C T)$ mice differed from $\beta 2$ ko mice only in the thalamus $(p<0.05)$. $\beta 2 \operatorname{tr}(C T)$ did not differ from $\beta 2$ het mice in $\left[{ }^{86} \mathrm{Rb}\right]$ efflux from thalamic synaptosomes $(p>0.05)$. B, Effect of genotype on nicotineevoked GABA release. $\left[{ }^{3} \mathrm{H}\right] \mathrm{GABA}$ release was measured in response to a 12 sec exposure to 30 $\mu \mathrm{m}$ nicotine in four brain regions ( $n=4$ for each genotype). ANOVAs of each brain area showed a significant genotype effect on nicotine evoked $\left[{ }^{3} \mathrm{H}\right] \mathrm{GABA}$ release in all brain areas $(p<$ 0.0001 ). Post hoc Newman-Keuls tests showed the $\beta 2$ wt and $\beta 2$ het mice to be different from all other genotypes in all brain areas $(p<0.05)$. There was no increase in $\left[{ }^{3} \mathrm{H}\right] \mathrm{GABA}$ release in the $\beta 2 \operatorname{tr}(C T)$ compared with $\beta 2$ ko mice in any brain area $(p>0.05)$. No significant differences were seen for baseline release for any genotype in any brain area. Hipp., Hippocampus.

the thalamus that are functional and can regulate neurotransmitter release from synaptic terminals (Turner and Salt, 1998).

\section{Corticothalamic $\beta 2 \mathrm{nAChR}$ expression restores baseline PA behavior}

We tested PA behavior in $\beta 2 \operatorname{tr}(\mathrm{CT})$ mice and compared these mice with sibling controls of different genotypes (Fig. 4). In contrast to $\beta 2$ ko mice, which showed hypersensitive PA learning compared with control siblings (Picciotto et al., 1995), $\beta 2 \operatorname{tr}(\mathrm{CT})$ mice had PA performance similar to wild-type mice and had a significantly shorter latency to enter the dark chamber than $\beta 2$ ko mice (Fig. 4). Thus, restricted expression of $\beta 2$ subunitcontaining receptors to corticothalamic efferents is sufficient for normal PA behavior.

We showed previously that nicotine is ineffective in improving PA performance in $\beta 2$ ko mice (Picciotto et al., 1995). In the current study, although nicotine was able to enhance PA performance in wild-type mice [saline, $23.7 \pm 5.2 \mathrm{sec}(n=17)$; nicotine, $56.4 \pm 16.8 \sec (n=9)$; Newman-Keuls test; $p<0.05$ ], it had no effect on $\beta 2 \operatorname{tr}(\mathrm{CT})$ mice [saline, $31.8 \pm 6.6 \mathrm{sec}(n=29)$; nicotine, $26.7 \pm 1.6 \mathrm{sec}(n=11)]$. Thus, expression of high- 


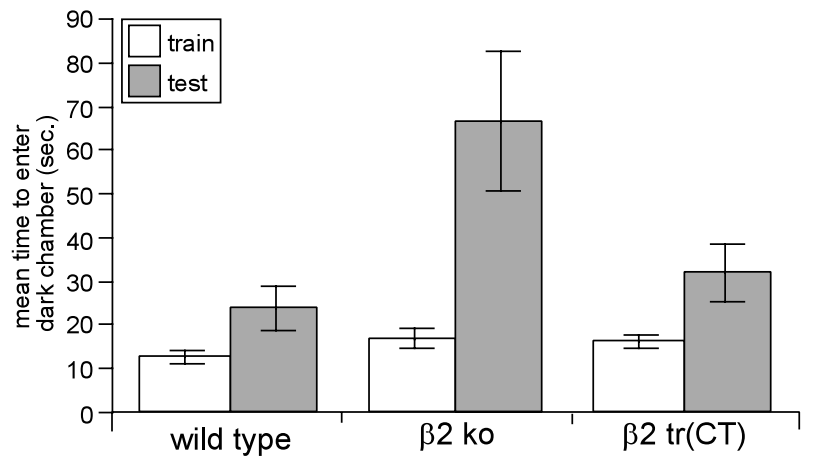

Figure 4. Expression of $\beta 2$ subunit-containing receptors in corticothalamic terminals is sufficient for normal baseline PA performance. PA performance was evaluated in wild-type ( $\beta 2$ het and $\beta 2 \mathrm{wt}$ ), $\beta 2 \mathrm{ko}$, and $\beta 2 \operatorname{tr}(\mathrm{CT})$ mice [wild type, $n=17 ; \beta 2 \mathrm{ko}, n=21 ; \beta 2 \operatorname{tr}(\mathrm{CT}), n=$ 29]. A repeated-measures ANOVA of the baseline PA performance with day (testing vs training) as the within-subject variable and genotype [wild type, $\beta 2 \mathrm{ko}$, and $\beta 2 \operatorname{tr}(\mathrm{CT})$ ] as the betweensubject variable revealed an interaction of day and genotype $\left(F_{(2,64)}=4.311 ; p<0.05\right)$. Post hoc Newman-Keuls tests showed the $\beta 2$ ko mice to have a longer latency to enter the dark compartment on testing than the wild-type and $\beta 2 \operatorname{tr}(\mathrm{CT})$ mice $(p<0.05)$.

affinity nAChRs on corticothalamic neurons rescues baseline performance, although it is not sufficient to restore nicotinemediated enhancement of PA. These data suggest that nAChRs in other brain regions, such as the amygdala, striatum, or hippocampus, may be critical for the nicotine-mediated enhancement of PA learning.

The restored baseline PA learning in $\beta 2 \operatorname{tr}(\mathrm{CT})$ mice was attributable to $\beta 2$ subunit expression rather than transgene insertion, because no difference in baseline PA behavior was seen in mice carrying either the NSE-tTA transgene or the TetOp- $\beta 2$ transgene alone (Fig. 5A). The ability of transgenic expression from a different locus to restore a phenotype altered in the $\beta 2$ ko mice also confirms that the original phenotype was not attributable to effects of flanking genes surrounding the mutant allele (Banbury Conference on Genetic Background in Mice, 1997; Bolivar et al., 2000). Furthermore, the difference in PA performance in $\beta 2 \operatorname{tr}(\mathrm{CT})$ mice cannot be explained by altered pain sensitivity because no differences were seen in shock reactivity at intensities similar to those used in PA training (Fig. 5B).

\section{Developmental expression of $\beta 2 \mathrm{nAChRs}$ is critical for baseline PA}

One possible role for high-affinity nAChRs in thalamus could be to modulate sensory processing through thalamus to cortex by altering synaptic strength in glutamatergic neurons during development. To determine whether high-affinity nAChRs act acutely to regulate PA behavior in the adult or whether the receptors are critical earlier in development, adult mice were administered 100 $\mu \mathrm{g} / \mathrm{ml}$ dox in their drinking water for $30 \mathrm{~d}$ to abolish expression of high-affinity nAChRs in $\beta 2 \operatorname{tr}(\mathrm{CT})$ mice (Fig. 6A). dox administration had no effect on PA performance of mice of any genotype (Fig. 6B). These data suggest that expression of $\beta 2$ subunitcontaining nAChRs in corticothalamic efferents during development results in a long-lasting alteration of this pathway that facilitates PA learning in the adult.

\section{Discussion}

We generated transgenic mice with inducible, region-specific expression of $\beta 2$ subunit-containing $\mathrm{nAChRs}$ in corticothalamic projection neurons. Using these mice, we showed that alterations in neurotransmission through $\mathrm{nAChRs}$ during development can
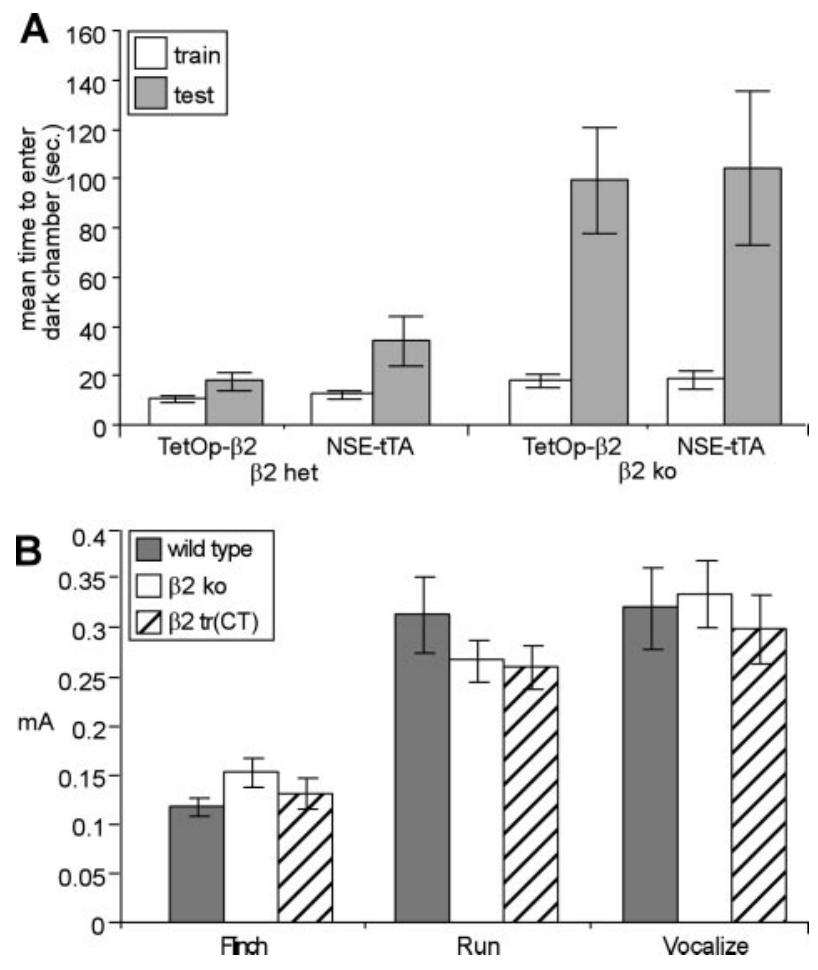

Figure 5. The PA phenotype is not attributable to transgene insertion or alteration of shock sensitivity. $A$, The insertion of the individual transgenes on the $\beta 2$ het or $\beta 2$ ko backgrounds does not affect PA performance. $\beta 2$ het and $\beta 2$ ko mice with either the Tet0p- $\beta 2$ or NSE-tTA transgene alone were tested for PA behavior ( $\beta 2$ het/TetOp- $\beta 2, n=8$; $\beta 2$ het/NSE-tTA, $n=$ 9; $\beta 2$ ko/Tet0p- $\beta 2, n=15 ; \beta 2$ ko/NSE-tTA, $n=12$ ). Repeated-measures ANOVA with day (testing vs training) as the within-subject variable and genotype ( $\beta 2$ het vs $\beta 2$ ko) and transgene (Tet0p- $\beta 2$ vs NSE-tTA) as between-subject variables showed an interaction of day and genotype $\left(F_{(1,40)}=9.015 ; p<0.01\right)$ but no main effect or interaction with single transgenes. $B$, The altered PA phenotype is not a result of differential shock reactivity. Mice of different genotypes [ $\beta 2$ wt and $\beta 2$ het, $\beta 2$ ko and $\beta 2 \operatorname{tr}(\mathrm{CT})$ ] were tested for response to increasing levels of shock. ( $\beta 2$ wt and $\beta 2$ het were combined as "wild types" for subsequent analysis). Mean lowest shock that evoked the responses flinch, run, and vocalize for each of the three genotypes ( $n=7$ per genotype) is plotted. ANOVA showed no effect of genotype ( $p>0.05$ in all cases).

affect PA performance in the adult. Nicotine treatment during development is known to have neurodevelopmental and behavioral consequences. In humans, maternal smoking has been associated with babies of lower birth weight, increased risk of sudden infant death syndrome, and increased risk of psychiatric disorders in childhood and adolescence (Ernst et al., 2001), including ADHD (Milberger et al., 1996; Milberger et al., 1998). Cognitive impairments and hyperactivity have also been reported in animals exposed to nicotine during development (Genedani et al., 1983; Sorenson et al., 1991; Pennington et al., 1994; Shacka et al., 1997). A blunting of both cholinergic and catecholaminergic function is also seen in rats prenatally exposed to nicotine (Navarro et al., 1988, 1989; Oliff and Gallardo, 1999). Thus, expression of nAChRs during prenatal and postnatal development is likely to be critical for normal cognitive behavior in the adult.

The first 2 weeks of life are a critical period for maturation of glutamatergic synapses on corticothalamic neurons, with targeting of glutamate receptor subunits such as mGluRla to the distal dendrites of these synapses during the second postnatal week of rat development (Liu et al., 1998). Chronic nicotine treatment at this time has been shown to enhance glutamatergic (NMDA receptor-mediated) transmission in the neocortex of rats (Aramakis and Metherate, 1998), resulting in a subsequent increase in 

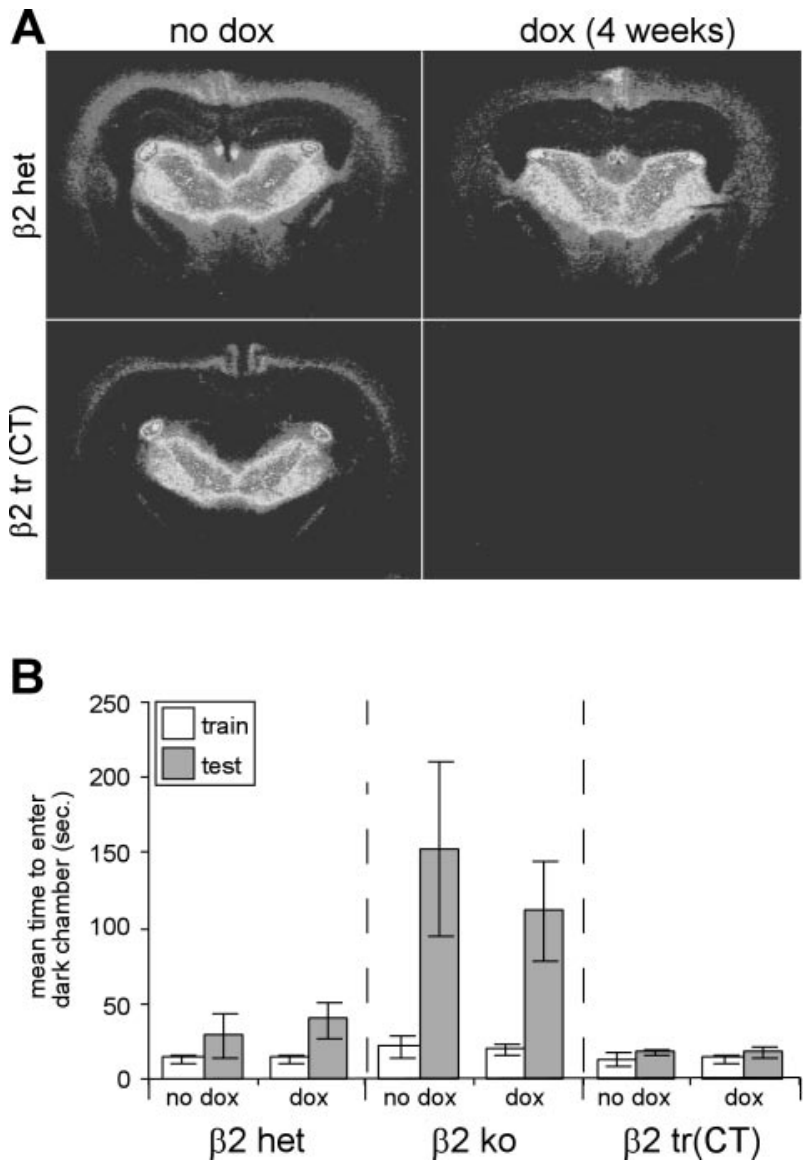

Figure 6. Expression of the $\beta 2$ subunit during development is necessary for normal PA learning. $A, \beta 2$ het, $\beta 2 \mathrm{ko}$, and $\beta 2 \operatorname{tr}(C \mathrm{C})$ mice were treated with dox $(100 \mu \mathrm{g} / \mathrm{ml})$ in their drinking water for 4 weeks. No change was seen in $\left[{ }^{125}\right.$ ]]A85380 binding in $\beta 2$ wt (data not shown) or $\beta 2$ het mice after dox treatment, but no binding was detectable in $\beta 2 \operatorname{tr}(\mathrm{CT})$ mice administered dox. $B$, Four weeks of dox treatment in adult mice does not alter PA performance in $\beta 2 \operatorname{tr}(\mathrm{CT})$ mice $[\beta 2$ het, no dox, $n=4 ; \beta 2$ het with dox, $n=6 ; \beta 2 \mathrm{ko}$, no dox, $n=4, \beta 2 \mathrm{ko}$ with dox, $n=9 ; \beta 2 \operatorname{tr}(\mathrm{CT})$, no dox, $n=10 ; \beta 2 \operatorname{tr}(\mathrm{CT})$ with dox, $n=11]$. A repeated-measures ANOVA with day (training vs testing) as the within-subject variable and dox treatment (on or off) and genotype [ $\beta 2$ het, $\beta 2 \mathrm{ko}$, and $\beta 2 \operatorname{tr}(\mathrm{CT})]$ as the between-subject variables showed an interaction of day and genotype $\left(F_{(2,39)}=13.382 ; p<0.01\right)$ but no main effect or interaction with dox.

NMDA receptor subunit NR2A mRNA expression in layer VI of the auditory cortex that lasts for 2 weeks (Hsieh et al., 2002). These data suggest that expression of high-affinity nAChRs during this period of development can affect maturation of glutamatergic synapses. In rat, the NSE promoter drives expression early in the development of layer VI neurons and remains on throughout development, with a dip on postnatal day 10, before rising again to adult levels by day 20 (Hamre et al., 1989). Our data suggest that the presence of $\beta 2$ subunit-containing nAChRs during these critical periods of synaptogenesis is essential for the long-term modulation of PA performance.

The nicotine-induced enhancement of PA learning in adult mice is not mediated by nAChRs on corticothalamic efferents, however. We hypothesize that $\mathrm{nAChRs}$ in other brain regions are critical for the effect of nicotine on PA learning in adulthood, and potential brain regions that could be explored include the amygdala (Riekkinen et al., 1993), striatum (Sandberg et al., 1984; Giordano et al., 1998), or hippocampus (Pope et al., 1985; Bailey et al., 1986), all of which have been identified as critical sites for plastic changes associated with consolidation of PA learning (McGaugh et al., 1996).
High-affinity nAChRs are normally expressed throughout the brain and are likely to affect the development and function of synaptic activity in many brain areas. Mutations in the $\alpha 4$ and $\beta 2$ subunits of the nAChR in several human families result in autosomal dominant nocturnal frontal lobe epilepsies (Sutor and Zolles, 2001), which have been associated with an increased probability of learning and developmental disorders (Gunduz et al., 1999; Verrotti et al., 2000). It should be noted, however, that it is unclear whether the cognitive impairment in these patients results directly from altered $\mathrm{nAChR}$ activity during development or indirectly from repeated seizures, which are known to cause cognitive impairment. We showed that mutation of the $\beta 2$ subunit in mice results in abnormal sensitivity to PA learning and have identified corticothalamic efferents as the anatomical locus for this effect. Abnormalities in nAChRs in human subjects may also result in developmental changes in corticothalamic signaling that could affect emotional learning. Prenatal exposure to nicotine in humans may desensitize and functionally downregulate highaffinity nAChRs, as is seen with chronic nicotine exposure in mice (Marks et al., 1993; Zachariou et al., 2001). Thus, chronic exposure to nicotine during development could alter nicotinic neurotransmission in corticothalamic circuits and lead to inappropriate emotional learning during adulthood.

\section{References}

Aramakis V, Metherate R (1998) Nicotine selectively enhances NMDA receptor-mediated synaptic transmission during postnatal development in sensory neocortex. J Neurosci 18:8485-8495.

Bailey EL, Overstreet DH, Crocker AD (1986) Effects of intrahippocampal injections of the cholinergic neurotoxin AF64A on open-field activity and avoidance learning in the rat. Behav Neural Biol 45:263-274.

Banbury Conference on Genetic Background in Mice (1997) Mutant mice and neuroscience: recommendations concerning genetic background. Neuron 19:755-759.

Bolivar V, Cook M, Flaherty L (2000) List of transgenic and knockout mice: behavioral profiles. Mamm Genome 11:260-274.

Caldarone BJ, George TP, Zachariou V, Picciotto MR (2000) Gender differences in learned helplessness behavior are influenced by genetic background. Pharmacol Biochem Behav 66:811-817.

Chen JS, Kelz MB, Zeng GQ, Sakai N, Steffen C, Shockett PE, Picciotto MR, Duman RS, Nestler EJ (1998) Transgenic animals with inducible, targeted gene expression in brain. Mol Pharmacol 54:495-503.

Corrigall WA, Coen KM, Adamson KL, Chow BL (1999) Manipulations of mu-opioid and nicotinic cholinergic receptors in the pontine tegmental region alter cocaine self-administration in rats. Psychopharmacology 145:412-417.

Ernst M, Moolchan ET, Robinson ML (2001) Behavioral and neural consequences of prenatal exposure to nicotine. J Am Acad Child Adolesc Psychiatry 40:630-641.

Genedani S, Bernardi M, Bertolini A (1983) Sex-linked differences in avoidance learning in the offspring of rats treated with nicotine during pregnancy. Psychopharmacology (Berl) 80:93-95.

Giordano M, Salado-Castillo R, Sanchez-Alvarez M, Prado-Alcala RA (1998) Striatal transplants prevent AF64A-induced retention deficits. Life Sci 63:1953-1961.

Guillery RW, Sherman SM (2002) Thalamic relay functions and their role in corticocortical communication: generalizations from the visual system. Neuron 33:163-175.

Gunduz E, Demirbilek V, Korkmaz B (1999) Benign rolandic epilepsy: neuropsychological findings. Seizure 8:246-249.

Hallanger AE, Levey AI, Lee HJ, Rye DB, Wainer BH (1987) The origins of cholinergic and other subcortical afferents to the thalamus in the rat. J Comp Neurol 262:105-124.

Hamre KM, Cassell MD, West JR (1989) The development of laminar staining for neuron-specific enolase in the rat somatosensory cortex. Dev Brain Res 46:213-220.

Hsieh CY, Leslie FM, Metherate R (2002) Nicotine exposure during a postnatal critical period alters NR2A and NR2B mRNA expression in rat auditory forebrain. Dev Brain Res 133:19-25. 
Kalivas PW, Churchill L, Romanides A (1999) Involvement of the pallidalthalamocortical circuit in adaptive behavior. Ann NY Acad Sci 877:64-70.

Kelz MB, Chen J, Carlezon Jr WA, Whisler K, Gilden L, Beckmann A, Steffen C, Zhang YJ, Marotti L, Self DW, Tkatch T, Baranauskas G, Surmeier DJ, Neve RL, Duman RS, Picciotto MR, Nestler EJ (1999) Expression of the transcription factor Delta FosB in the brain controls sensitivity to cocaine. Nature 401:272-276.

Léna C, Changeux JP (1997) Role of $\mathrm{Ca}^{2+}$ ions in nicotinic facilitation of GABA release in mouse thalamus. J Neurosci 17:576-585.

Liu XB, Munoz A, Jones EG (1998) Changes in subcellular localization of metabotropic glutamate receptor subtypes during postnatal development of mouse thalamus. J Comp Neurol 395:450-465.

Lu Y, Grady S, Marks MJ, Picciotto M, Changeux JP, Collins AC (1998) Pharmacological characterization of nicotinic receptor-stimulated GABA release from mouse brain synaptosomes. J Pharmacol Exp Ther 287:648-657.

Luetje CW, Patrick J (1991) Both $\alpha$-and $\beta$-subunits contribute to the agonist sensitivity of neuronal nicotinic acetylcholine receptors. J Neurosci 11:837-845.

Marks MJ, Grady SR, Collins AC (1993) Downregulation of nicotinic receptor function after chronic nicotine infusion. J Pharmacol Exp Ther 266:1268-1276.

Marks MJ, Bullock AE, Collins AC (1995) Sodium channel blockers partially inhibit nicotine-stimulated $86 \mathrm{Rb}+$ efflux from mouse brain synaptosomes. J Pharmacol Exp Ther 274:833-841.

Marks MJ, Whiteaker P, Calcaterra J, Stitzel JA, Bullock AE, Grady SR, Picciotto MR, Changeux JP, Collins AC (1999) Two pharmacologically distinct components of nicotinic receptor-mediated rubidium efflux in mouse brain require the beta 2 subunit. J Pharmacol Exp Ther 289:1090-1103.

Marks MJ, Whiteaker P, Grady SR, Picciotto MR, McIntosh MJ, Collins AC (2002) Characterization of [125I] epibatidine binding and nicotinic agonist-mediated $86 \mathrm{Rb}$ efflux in interpeduncular nucleus and inferior colliculus of beta2 null mutant mice. J Neurochem 81:1102-1115.

Masterman DL, Cummings JL (1997) Frontal-subcortical circuits: the anatomic basis of executive, social and motivated behaviors. J Psychopharmacol 11:107-114.

McGaugh JL, Cahill L, Roozendaal B (1996) Involvement of the amygdala in memory storage: interaction with other brain systems. Proc Natl Acad Sci USA 93:13508-13514.

Meguro K, Yamaguchi S, Arai H, Nakagawa T, Doi C, Yamada M, Ikarashi Y, Maruyama Y, Sasaki H (1994) Nicotine improves cognitive disturbance in senescence-accelerated mice. Pharmacol Biochem Behav 49:769-772.

Milberger S, Biederman J, Faraone SV, Chen L, Jones J (1996) Is maternal smoking during pregnancy a risk factor for attention deficit hyperactivity disorder in children? Am J Psychiatry 153:1138-1142.

Milberger S, Biederman J, Faraone SV, Jones J (1998) Further evidence of an association between maternal smoking during pregnancy and attention deficit hyperactivity disorder: findings from a high-risk sample of siblings. J Clin Child Psychol 27:352-358.

Mukhin AG, Gundisch D, Horti AG, Koren AO, Tamagnan G, Kimes AS, Chambers J, Vaupel DB, King SL, Picciotto MR, Innis RB, London ED (2000) 5-iodo-A-85380, an alpha 4 beta 2 subtype-selective ligand for nicotinic acetylcholine receptors. Mol Pharmacol 57:642-649.

Nakagawasai O, Tadano T, Hozumi S, Tan-No K, Niijima F, Kisara K (2000) Immunohistochemical estimation of brain choline acetyltransferase and somatostatin related to the impairment of avoidance learning induced by thiamine deficiency. Brain Res Bull 52:189-196.

Navarro HA, Seidler FJ, Whitmore WL, Slotkin TA (1988) Prenatal exposure to nicotine via maternal infusions: effects on development of catecholamine systems. J Pharmacol Exp Ther 244:940-944.

Navarro HA, Seidler FJ, Eylers JP, Baker FE, Dobbins SS, Lappi SE, Slotkin TA (1989) Effects of prenatal nicotine exposure on development of central and peripheral cholinergic neurotransmitter systems. Evidence for cholinergic trophic influences in developing brain. J Pharmacol Exp Ther 251:894-900.

Oliff HS, Gallardo KA (1999) The effect of nicotine on developing brain catecholamine systems. Front Biosci 4:D883-D897.

Paxinos G, Franklin K (1997) The mouse brain in stereotaxic coordinates, Ed 2. San Diego: Academic.

Pennington SN, Sandstrom LP, Shibley Jr IA, Long SD, Beeker KR, Smith Jr CP, Lee K, Jones TA, Cummings KM, Means LW (1994) Biochemical changes, early brain growth suppression and impaired detour learning in nicotine-treated chicks. Brain Res Dev Brain Res 83:181-189.

Picciotto MR, Zoli M, Léna C, Bessis A, Lallemand Y, Le Novère N, Vincent P, Merlo Pich E, Brulet P, Changeux J-P (1995) Abnormal avoidance learning in mice lacking functional high-affinity nicotine receptor in the brain. Nature 374:65-67.

Pope CN, Englert LF, Ho BT (1985) Passive avoidance deficits in mice following ethylcholine aziridinium chloride treatment. Pharmacol Biochem Behav 22:297-299.

Riekkinen Jr P, Riekkinen M, Sirvio J (1993) Cholinergic drugs regulate passive avoidance performance via the amygdala. J Pharmacol Exp Ther 267:1484-1492.

Sandberg K, Sanberg PR, Hanin I, Fisher A, Coyle JT (1984) Cholinergic lesion of the striatum impairs acquisition and retention of a passive avoidance response. Behav Neurosci 98:162-165.

Shacka JJ, Fennell OB, Robinson SE (1997) Prenatal nicotine sexdependently alters agonist-induced locomotion and stereotypy. Neurotoxicol Teratol 19:467-476.

Sorenson CA, Raskin LA, Suh Y (1991) The effects of prenatal nicotine on radial-arm maze performance in rats. Pharmacol Biochem Behav 40:991-993.

Sutor B, Zolles G (2001) Neuronal nicotinic acetylcholine receptors and autosomal dominant nocturnal frontal lobe epilepsy: a critical review. Pflügers Arch 442:642-651.

Turner JP, Salt TE (1998) Characterization of sensory and corticothalamic excitatory inputs to rat thalamocortical neurones in vitro. J Physiol (Lond) 510:829-843.

Verrotti A, Domizio S, Guerra M, Sabatino G, Morgese G, Chiarelli F (2000) Childhood epilepsy with occipital paroxysms and benign nocturnal childhood occipital epilepsy. J Child Neurol 15:218-221.

Wakschlag LS, Pickett KE, Cook Jr E, Benowitz NL, Leventhal BL (2002) Maternal smoking during pregnancy and severe antisocial behavior in offspring: a review. Am J Public Health 92:966-974.

Zachariou V, Caldarone BJ, Weathers-Lowin A, George TP, Elsworth JD, Roth RH, Changeux JP, Picciotto MR (2001) Nicotine receptor inactivation decreases sensitivity to cocaine. Neuropsychopharmacology 24:576-589.

Zoli M, Léna C, Picciotto MR, Changeux JP (1998) Identification of four classes of brain nicotinic receptors using $\beta 2$-mutant mice. J Neurosci 18:4461-4472. 